\title{
Alternative substrates for cultivating oyster mushrooms (Pleurotus ostreatus)
}

\author{
Mashudu R Masevhe ${ }^{1,2 *}$, Puffy Soundy ${ }^{3}$ and Nicolette $\mathrm{J} \mathrm{Taylor}^{2}$
}

\begin{abstract}
1 Agricultural Research Council-Institute for Tropical and Subtropical Crops, Nelspruit, South Africa; current address: Department of Plant Production, Soil Science and Agricultural Engineering, University of Limpopo, Polokwane, South Africa

${ }^{2}$ Department of Plant Production and Soil Science, University of Pretoria, Pretoria, South Africa

${ }^{3}$ Department of Crop Science, Faculty of Science, Tshwane University of Technology, Pretoria, South Africa

*Corresponding author, email: mashudu.masevhe@ul.ac.za
\end{abstract}

\begin{abstract}
Wheat straw has generally been used as the main substrate for cultivating oyster mushrooms (Pleurotus ostreatus); however, in South Africa it is becoming expensive for small-scale farmers to utilise. Therefore, the main objective of the study was to investigate the use of alternative, but suitable substrates for planting oyster mushrooms. Wheat straw (control), wood chips and thatch grass, selected on account of their year-round availability and low cost, were tested with two drainage treatments (drained or not drained) and replicated four times. Wheat straw showed no contamination, whereas there was contamination in thatch grass and wood chips from weeks 1 to 4 . At harvest, a significantly higher cumulative number of flushes, caps and fresh mass of oyster mushrooms was observed in wheat straw and thatch grass compared with wood chips. The results demonstrated that thatch grass could be used as a viable alternative to the commonly used wheat straw.
\end{abstract}

Keywords: colonisation, contamination, thatch grass, wheat straw, wood chips

\section{Introduction}

For successful mushroom cultivation, three factors must be considered, namely reliable spawn, good substrate and a conducive environment (Rajapakse et al. 2007). Substrates in mushroom cultivation have the same function as soil in plant production (Kwon and Kim 2004). Many species of Pleurotus are commonly grown on a wide range of lignocellulosic materials (Sanchez 2004). Different substrates can be recommended per region due to local availability of agricultural wastes (Cohen et al. 2002). The ideal medium for cultivation of edible fungi must be sterile and rich in essential nutrients (Wood and Hartley 1988; Kwon and Kim 2004), such as nitrogen (N), phosphorus (P), potassium $(\mathrm{K})$, magnesium $(\mathrm{Mg})$ and iron $(\mathrm{Fe})$. Most commonly used substrates include sawdust, cottonseed straw, cereal straw, corncob, sugar cane straw and other plant fibres with high cellulose content (Ragunathan et al. 1996; Kwon and Kim 2004). According to Labuschagne et al. (2000), wheat straw has been the main substrate used for cultivating Pleurotus ostreatus. However, Bughio (2001) successfully planted Pleurotus ostreatus on a combination of wheat straw, cotton boll straw, paddy straw, sugarcane and sorghum leaves.

The substrate can also be supplemented, if necessary, with additional $\mathrm{N}$ sources, such as wheat bran, oat bran, copra cake (from spent coconut), rice bran, sorghum or millet in order to obtain quality mushrooms. Additives such as gypsum, limestone and chalk can function as $\mathrm{pH}$ buffers in a substrate (Kwon and Kim 2004). Although Pleurotus species can be produced from various substrate types or residues, productivity and biological efficiency will vary according to strains and substrates used (Bernardi et al.
2007). Different substrates can, therefore, be recommended per region depending on local availability of agricultural wastes (Cohen et al. 2002).

Cultivation of oyster mushrooms using different substrates has been studied extensively (Poppe 2004). However, there is no specific information on the usage of thatch grass and wood chips as alternatives to wheat straw for oyster mushroom cultivation. Thatch grass can be freely collected from the veld and wood chips are waste products from wood-milling companies. These alternative substrates need to be studied in order to determine their suitability for use by both commercial and small-scale farmers in mushroom production. Therefore, the present study was conducted to investigate the suitability of two alternative substrates (thatch grass and wood chips) with regard to the rate of colonisation amongst the substrates, the amount of contamination, and to compare mineral content of the substrates and nutritional differences between oyster mushrooms produced.

\section{Materials and methods}

\section{Study site}

The experiment was conducted in a custom-made growth room at the Experimental Farm of the Agricultural Research Council-Institute for Tropical and Subtropical Crops (ARC-ITSC) situated in Mbombela Municipality $\left(25^{\circ} 27^{\prime} \mathrm{S}, 30^{\circ} 58^{\prime} \mathrm{E} ; 650 \mathrm{~m}\right.$ above sea level), Mpumalanga, South Africa. Temperature $\left({ }^{\circ} \mathrm{C}\right)$ and relative humidity $(\mathrm{RH}$; $\%$ ) in the growth room were measured using a HOBO Data 
Logger (U14-001 LCD Temperature/RH Data Logger, Onset Computer Corporation, Bourne, MA, USA).

\section{Experimental design and pasteurisation of substrates}

The layout of the experiment was a completely randomised design with six treatments consisting of a factorial combination of three types of substrates and two levels of drainage, with each treatment replicated four times. The three types of substrates were wheat straw (control), wood chips and thatch grass (Figure 1). Single bales of wheat straw $(10 \mathrm{~kg})$, wood chips $(20 \mathrm{~kg})$ and thatch grass $(15 \mathrm{~kg})$ were boiled separately in $225 \mathrm{~L}$ drums. Substrates were pasteurised using the method outlined by Kang (2004). Drained substrates were boiled and excess water allowed to leach out before inoculation with spawn, whereas undrained substrates were inoculated with spawn immediately after boiling. Culture bags were $45 \mu \mathrm{m}$ polyethylene bags filled with a mixture of substrate and spawn (1 kg) to a total weight of $7 \mathrm{~kg}$. Wheat straw substrate was sourced from Marble Hall (Limpopo, South Africa), wood chips were sourced from DENSA, a wood company (Lydenburg/Sabie Road, Mpumalanga), whereas thatch grass was collected from the veld (Mbombela, Mpumalanga).

\section{Data collection}

Culture bags were evaluated for both colonisation and contamination. Evaluation for colonisation began shortly after inoculation until full colonisation, whereas contamination by mostly Trichoderma species was evaluated on a weekly basis using a rating-scale method of between 0 and $100 \%$ as outlined by Tesio (2003). After full colonisation, culture bags were cross cut from top to bottom to facilitate growth of mushroom flushes.

Mature oyster mushrooms were harvested three weeks after planting. These were pulled manually from the culture bags and kept in brown paper bags to avoid moisture loss, and taken to the laboratory for post-harvest analysis. Growth parameters recorded included cumulative number of harvests, number of flushes, number of caps and fresh mass.

\section{Post-harvest analysis}

After recording growth parameters, samples were kept in two separate plastic bags with caps or stalks and stored in a deep freezer $\left(-21^{\circ} \mathrm{C}\right)$ for further analysis. These samples were then sent on ice to ARC-API Laboratory Services for chemical analysis. Mineral analysis of samples of wheat straw, wood chips and thatch grass substrate were analysed at the ARC-ITSC Soil Science Laboratory using standard procedures (for $\mathrm{P}, \mathrm{K}, \mathrm{Mg}, \mathrm{Fe}$, calcium [Ca], zinc $[\mathrm{Zn}]$, copper [Cu], manganese [Mn] and boron [B]) as outlined by Isaac and Johnson (1992). The nutrient concentrations were measured with an atomic absorption flame spectrophotometer (Varian Spectra AA 250 Plus, Mulgrave, Australia).

\section{Analysis of chemical composition of oyster mushrooms} Both caps and stalks (100 g each) were chemically analysed for ash, carbohydrates, dry matter, moisture, fat and protein content. Organic matter was analysed using the method outlined by Harris (1970). Carbohydrates, moisture content, crude protein, ash and fat were analysed using appropriate SANAS-accredited methods outlined by Greenfield and Southgate (2003). Dry matter content was determined using the method outlined by Mertens (2002). Fats were dissolved in ether and evaporated at $105^{\circ} \mathrm{C}$ using the Kjeldahl method outlined by Greenfield and Southgate (2003).

\section{Cost and economic analysis of substrates}

Wheat straw was bought from a farm in Marble Hall at a cost of R25.00 per $10 \mathrm{~kg}$ bale. The transport cost was R1 000.00 (480 km return trip) using a 1 ton truck with a trailer. In addition, the wheat straw was stored for three months to leach out compounds responsible for inhibiting mushroom growth. As wood chips were collected for free from a milling company close to the experimental site, costs were considered negligible. No costs were also associated with the thatch grass, as it was collected from the veld close to the experimental site and used immediately. In South Africa, button mushrooms are sold for R25 $\mathrm{kg}^{-1}$, whereas oyster mushrooms are sold for $\mathrm{R} 40 \mathrm{~kg}^{-1}$ in local retail markets.

\section{Statistical analysis}

Statistical analysis and interpretations were based on comparison of treatment means, as well as comparison between cumulative number of harvests, number of flushes, number of caps and fresh mass. The collected data were

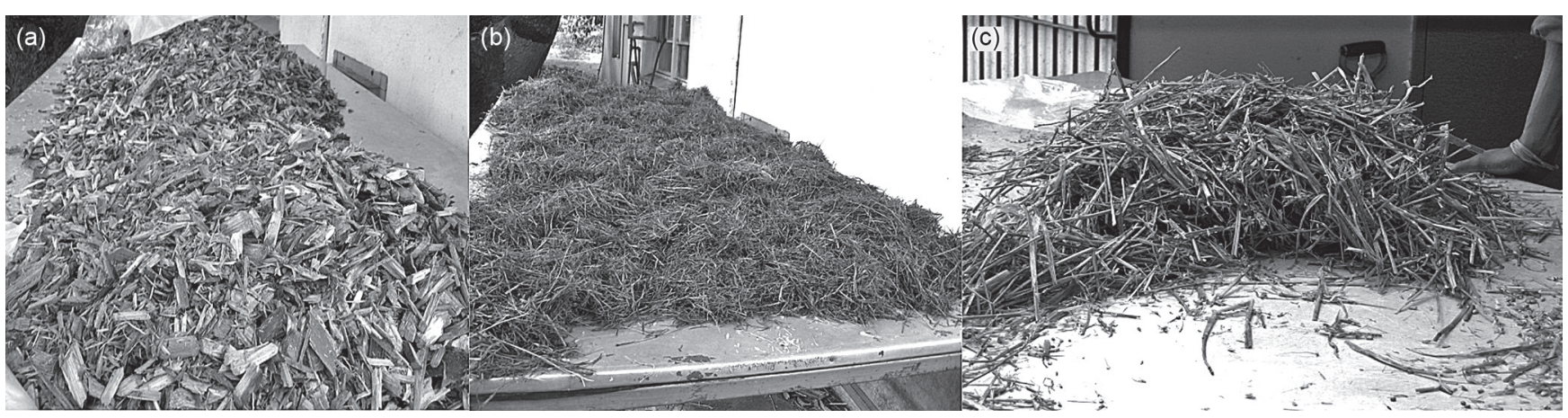

Figure 1: Sterilised wood chips (a), thatch grass (b) and wheat straw (c; control) on a planting table before inoculation with oyster mushroom spawn 
subjected to analysis of variance (ANOVA) using the SAS 8.2 software package (SAS Institute, Inc., Cary, NC, USA, 1999-2001).

\section{Results and discussion}

\section{Rate of colonisation}

Mean daily temperature in the growth room varied between 19 and $27{ }^{\circ} \mathrm{C}$ during full colonisation with mycelia and fruiting, whilst $\mathrm{RH}$ was between $80 \%$ and $98 \%$ (Figures 2 and 3 ). These temperatures appear ideal because Shah et al. (2004) reported an optimal temperature of $25^{\circ} \mathrm{C}$ for full mycelia colonisation and fruiting. There were highly significant differences $(P<0.05)$ in the percentage colonisation of wheat straw compared with either wood chips or thatch grass from days 1 to 8 (Figure 2).

On day 1 , wheat straw showed $65 \%$ colonisation compared with $50 \%$ and $45 \%$ colonisation for wood chips and thatch grass, respectively. Thereafter, wood chips and thatch grass showed lower rates of colonisation compared with that of wheat straw from days 1 to 8 . This may be due to low temperatures and $\mathrm{RH}$ in the growth room. In

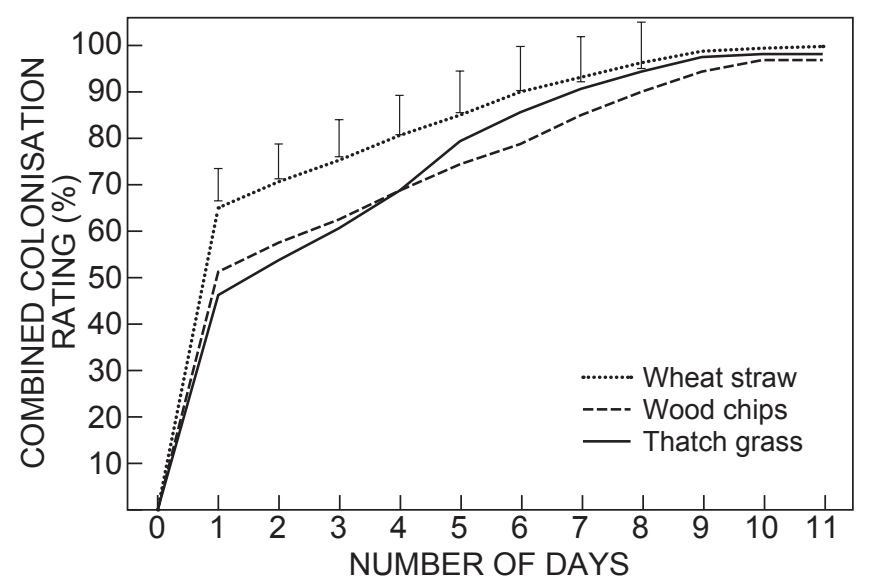

Figure 2: Rate of percentage colonisation for wheat straw, wood chips and thatch grass media from day 0 to day 11. Error bars represent LSD means $(P<0.05)$ addition, it took 8 days to attain full colonisation of wheat straw with mycelia, whereas full colonisation of wood chips and thatch grass was attained on days 9 to 10 (Figure 2). The present results were not inconsistent with the findings of Tan (1981), Shah et al. (2004), Mondal et al. (2010) and Khan et al. (2012), who reported that spawn took 2-3 weeks (14-21 days) to achieve full colonisation. Moreover, Khan (2009) reported that Pleurotus ostreatus took 24-25 days for completion of spawn running on wheat straw substrate. This may be due to the environmental conditions and the ability of available minerals in wheat straw to support oyster mushroom growth. From days 9 to 11, no significance difference in percentage colonisation was observed between the growing media. This indicated that wheat straw, wood chips and thatch grass had attained full colonisation by this time, although significant differences were observed at early stages of colonisation. Wheat straw was ideal for increasing the colonisation percentage of oyster mushrooms compared with wood chips and thatch grass. Grown mushrooms should be able to colonise an area quickly before other parasitic fungi can cover a designated area (van Nieuwenhuijzen 2007). The variation observed may be due to environmental differences, hygiene and the viability of oyster mushroom spawn.

\section{Comparison between substrate drainage and rate of colonisation}

The extent of drainage did not significantly affect rate of colonisation from days 1 to 4 (Figure 4). Undrained wheat straw did not differ significantly to drained wheat straw in terms of rate of colonisation from days 7 to 9 . Furthermore, undrained wheat straw attained $100 \%$ colonisation from days 9 to 11, whereas drained wheat straw did not attain full colonisation (Figure 4). Mane et al. (2007) reported a range of 12-14 days for full spawn running in various Pleurotus species on lignocellulosic substrates, although the present results concur with the spawn running periods reported above for Pleurotus species.

Undrained thatch grass showed an increased rate of colonisation compared with drained thatch grass from days 6 to 9 . Undrained thatch grass attained $100 \%$ colonisation at days 9 to 11, indicating that the polyethylene bags were fully colonised in two weeks (Figure 4). There was no significant

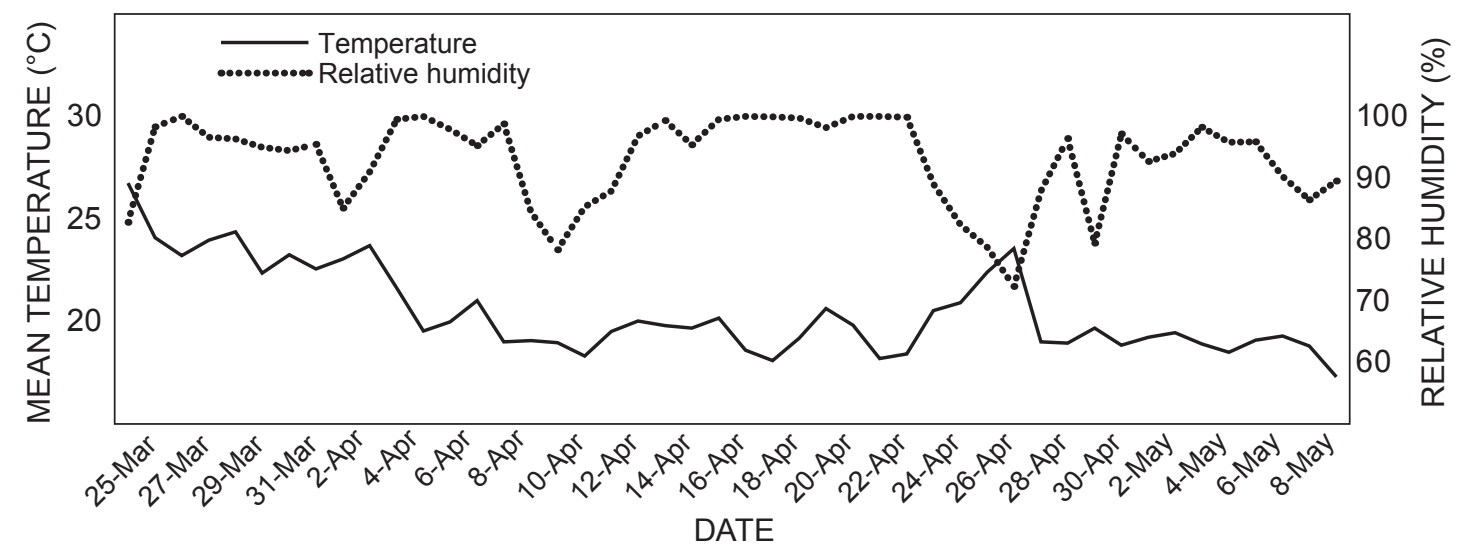

Figure 3: Mean temperature and relative humidity recorded from 25 March 2011 to 9 May 2011 in a hut house during the experiment 
difference $(P<0.05)$ in percentage colonisation between drained and undrained wood chips from days 0 to 11 . Mycelial growth is a preliminary step that creates suitable internal conditions for fruiting and also is a vital factor in mushroom cultivation because at the end of the day, farmers are willing for better yield (Pokhrel et al. 2009).

\section{Amount of contamination}

Percentage contamination exhibited no significance differences $(P<0.05)$ amongst the treatments during week 1 (Table 1). Wood chips did not differ significantly from wheat straw in relation to amount of contamination in week 2. However, wood chips showed higher percentage contamination $(16 \%)$ compared with thatch grass $(8 \%)$ in week 2, whereas wheat straw $(0 \%)$ showed no contamination. Van Niewenhuijzen (2007) stated that a fast

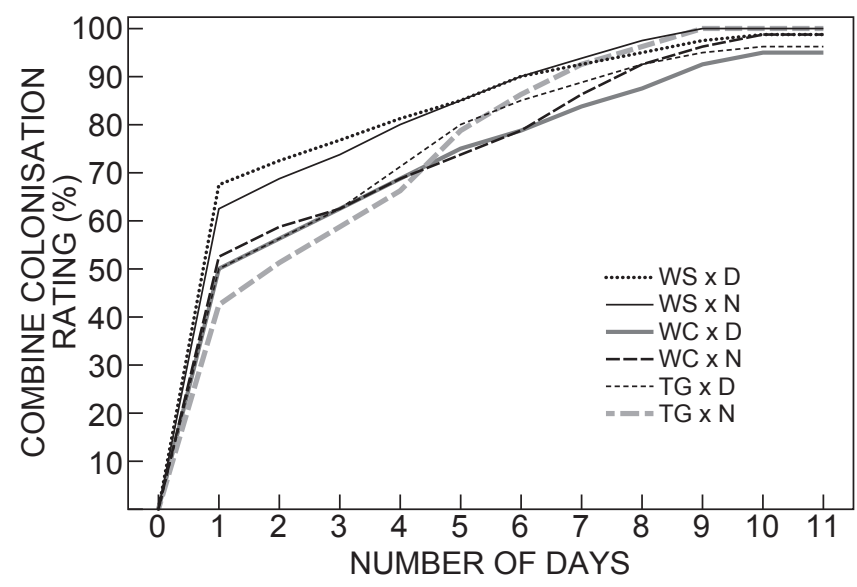

Figure 4: Rate of colonisation of wheat straw (WS), wood chips (WC) and thatch grass (TG) substrates, either drained (D) or undrained $(\mathrm{N})$, from day 0 to day 11 . No significant differences among treatments were observed

Table 1: Contamination percentages for three growing media evaluated over four weeks. Within the same column, means followed by the same letter are not statistically different at $P=0.05$

\begin{tabular}{lcccc}
\hline \multirow{2}{*}{ Treatment } & \multicolumn{4}{c}{ Evaluation week } \\
\cline { 2 - 5 } & 1 & 2 & 3 & 4 \\
\hline Wheat straw & 0.00 & $0.00^{\mathrm{b}}$ & $0.00^{\mathrm{b}}$ & $0.00^{\mathrm{b}}$ \\
Wood chips & 3.38 & $16.25^{\mathrm{a}}$ & $27.75^{\mathrm{a}}$ & $36.88^{\mathrm{a}}$ \\
Thatch grass & 5.00 & $7.50^{\mathrm{ab}}$ & $10.00^{\mathrm{ab}}$ & $12.50^{\mathrm{ab}}$ \\
LSD $(\alpha<0.05)$ & $\mathrm{ns}$ & 14.75 & 22.46 & 24.00 \\
$P$-value & 0.3097 & 0.0161 & 0.0107 & 0.0130 \\
\hline
\end{tabular}

rate of colonisation by mushrooms within the growing area can suppress the development of other fungi or bacteria. Wood chips were more susceptible to contamination compared with thatch grass, whereas wheat straw did not show any contamination during the experiment (Table 1).

In week 3 wood chips showed significantly increased percentage contamination $(28 \%)$ compared with thatch grass $(10 \%)$. This may be due to variation in moisture loss within the different substrates, thereby influencing development of other fungi or bacteria. On-farm hygiene can also contribute to contamination of both substrate and mushrooms (van Niewenhuijzen 2007). In week 4, wood chips significantly differed from wheat straw in amount of contamination. Moreover, wood chips showed the highest percentage contamination (37\%) compared with thatch grass $(13 \%)$ and wheat straw $(0 \%)$ (Table 1). This indicated that wheat straw significantly suppressed contamination throughout the production period. Clearly, both wood chips and thatch grass were not effective in suppressing contamination. Sofi et al. (2014) indicated that nutrientpoor substrates exhibited low mycelial densities, making them prone to contamination especially by green mould. According to Kumari and Achal (2008), contamination can be caused by improper pasteurisation of straw and the availability of contaminants in a substrate.

\section{Mineral composition of substrates}

Thatch grass had higher $\mathrm{N}$ content $(1.136 \%)$ than both wheat straw $(0.560 \%)$ and wood chips $(0.080 \%)$ (Table 2$)$. Rajarathnam et al. (1988) indicated that $\mathrm{N}$ plays an important role in building biomass of Pleurotus ostreatus. Thatch grass had significantly higher available $\mathrm{N}$ compared with both wheat straw and wood chips. This finding is also supported by Yildiz et al. (2002), who reported that the natural substrates (i.e. woods) on which Pleurotus species grow are very poor in $\mathrm{N}$ content, nevertheless fruit bodies are produced. Upadhyay et al. (2002) reported that Pleurotus species have the capability to fix atmospheric N.

Thatch grass had a significantly higher $\mathrm{P}$ content $(0.161 \%)$ compared with both wheat straw $(0.054 \%)$ and wood chips $(0.001 \%)$. In contrast, wheat straw contained a higher amount of $\mathrm{K}(0.907 \%)$ compared with both thatch grass $(0.537 \%)$ and wood chips $(0.037 \%)$.

In terms of Ca levels, thatch grass, wheat straw and wood chips varied significantly $(0.490 \%, 0.340 \%$ and $0.067 \%$, respectively). Chiu et al. (1998) reported that agricultural wastes can be used to supply $\mathrm{Ca}$ for oyster mushroom growth and yield. In addition, application of poultry manure can be used to supplement and compensate for the lack of $\mathrm{Ca}, \mathrm{Cu}, \mathrm{Mn}$ and $\mathrm{Fe}$ in a nutrient-deficient

Table 2: Mineral analysis of different growing media. Within the same column, means followed by the same letter are not statistically different at $P=0.05$

\begin{tabular}{|c|c|c|c|c|c|c|c|c|c|c|c|}
\hline \multirow{2}{*}{ Treatment } & \multicolumn{5}{|c|}{ Element (\%) } & \multicolumn{5}{|c|}{ Element $\left(\mathrm{mg} \mathrm{kg}^{-1}\right)$} & \multirow{2}{*}{$\begin{array}{l}\mathrm{N}: \mathrm{K} \\
\text { ratio }\end{array}$} \\
\hline & $\mathrm{N}$ & $P$ & $\mathrm{~K}$ & $\mathrm{Ca}$ & $\mathrm{Mg}$ & $\mathrm{Zn}$ & $\mathrm{Cu}$ & $\mathrm{Mn}$ & $\mathrm{Fe}$ & $B$ & \\
\hline Wheat straw & $0.560^{b}$ & $0.054^{b}$ & $0.907^{a}$ & $0.340^{b}$ & $0.108^{b}$ & $33.00^{b}$ & $24.33^{a}$ & $71.33^{b}$ & $845.00^{a}$ & $7.53^{a}$ & $0.63^{b}$ \\
\hline Wood chips & $0.080^{c}$ & $0.001^{c}$ & $0.037^{c}$ & $0.067^{c}$ & $0.024^{c}$ & $8.67^{c}$ & $3.00^{c}$ & $48.33^{c}$ & $235.00^{c}$ & $3.97^{c}$ & $2.07^{a}$ \\
\hline Thatch grass & $1.136^{a}$ & $0.161^{\mathrm{a}}$ & $0.537^{b}$ & $0.490^{\mathrm{a}}$ & $0.282^{\mathrm{a}}$ & $36.33^{a}$ & $11.33^{b}$ & $147.00^{a}$ & $408.33^{b}$ & $10.27^{a}$ & $2.13^{a}$ \\
\hline $\operatorname{LSD}(\alpha<0.05)$ & 0.041 & 0.002 & 0.023 & 0.021 & 0.004 & 2.978 & 0.942 & 3.940 & 34.010 & 0.553 & 0.447 \\
\hline$P$-value & $<0.0001$ & $<0.0001$ & $<0.0001$ & $<0.0001$ & $<0.0001$ & $<0.0001$ & $<0.0001$ & $<0.0001$ & $<0.0001$ & $<0.0001$ & 0.0003 \\
\hline
\end{tabular}


substrate for oyster mushroom cultivation (Bandara et al. 2006). Available Mg content significantly differed for thatch grass $(0.282 \%)$ compared with both wheat straw $(0.108 \%)$ and wood chips $(0.024 \%)$. Wheat straw contained a higher amount of $\mathrm{Fe}\left(845.0 \mathrm{mg} \mathrm{kg}{ }^{-1}\right)$ compared with both thatch grass (408.3 $\mathrm{mg} \mathrm{kg}^{-1}$ ) and wood chips (235.0 $\mathrm{mg} \mathrm{kg}^{-1}$ ) (Table 2). In general, wood chips had the lowest mineral (e.g. N, P, K, Ca, Mg and Fe) quantities, far below critical threshold levels required for oyster mushroom production, compared with the other substrates. The lower mineral content of wood chips was reflected in the production of fewer cumulative numbers of flushes and caps and lower fresh mass of oyster mushrooms.

\section{Nutritional composition of oyster mushrooms}

There were no significant differences $(P<0.05)$ between treatments (wheat straw, wood chips and thatch grass) in terms of the chemical composition (i.e. ash, fat, protein and carbohydrates) of oyster mushrooms (Table 3 ). Other studies have reported protein contents ranging from $22.89 \%$ to $25.97 \%$, which were far higher than the current results, when rice straw was used as a substrate. The fat and carbohydrates content ranged from $1.03 \%$ to $1.50 \%$ and $30.24 \%$ to $42.26 \%$, respectively. These results indicate that carbohydrate and protein contents are dependent on the substrate used (Wang et al. 2001). However, in the present study, all mineral nutrients were available in harvested oyster mushrooms in lower percentages, regardless of the different substrates (Table 3).
The substrates in the present experiment had moisture contents ranging from $89.94 \%$ to $90.84 \%$. This finding was similar to that of Dunkwal and Jood (2009), who reported that oyster mushrooms grown on wheat straw and brassica straw contained moisture contents of $89.68 \%$ and $88.98 \%$ on a fresh weight basis. Oyster mushrooms are soft in nature due to the high moisture content at a young stage but tend to lose moisture with maturity (Prakash et al. 2011). Mushroom fungi are regarded as a good source of protein, with high vitamins and lower calories, and free from cholesterol (Selvi et al. 2007). Generally, no growing medium was superior to the other substrates in relation to chemical composition.

\section{Harvesting periods}

Oyster mushroom harvesting started at \pm 66 days after planting. At first harvest, thatch grass produced a higher number of flushes compared with both wheat straw and wood chips (Figure 5). Thatch grass had a higher cumulative number of flushes, although each harvest differed in number of flushes and caps and fresh mass produced during the entire production. However, wheat straw had a similar number of flushes compared with thatch grass. Wheat straw produced a similar number of caps from the first harvest to the sixth harvest. Surprisingly, wood chips had three harvests only compared with both wheat straw and thatch grass (Figure 5). This study was not inconsistent with the findings of Sharma et al. (2013), who harvested only two flushes of mushrooms for each treatment (rice

Table 3: Nutritional value of oyster mushrooms harvested in different growing media

\begin{tabular}{lccccccc}
\hline \multirow{2}{*}{ Treatment } & \multicolumn{9}{c}{ Nutritional value (\%) } \\
\cline { 2 - 8 } & Fresh mass & Dry matter & Moisture & Ash & Fat & Protein & Carbohydrates \\
\hline Wheat straw & 10.54 & 9.84 & 90.16 & 0.82 & 0.15 & 1.66 & 7.22 \\
Thatch grass & 9.92 & 9.16 & 90.84 & 0.68 & 0.09 & 1.67 & 6.74 \\
Wood chips & 10.76 & 10.06 & 89.94 & 0.44 & 0.08 & 2.45 & 7.09 \\
LSD $(\alpha<0.05)$ & $\mathrm{ns}$ & $\mathrm{ns}$ & $\mathrm{ns}$ & $\mathrm{ns}$ & $\mathrm{ns}$ & $\mathrm{ns}$ & $\mathrm{ns}$ \\
$P$-value & 0.803 & 0.766 & 0.766 & 0.114 & 0.473 & 0.582 & 0.960 \\
\hline
\end{tabular}
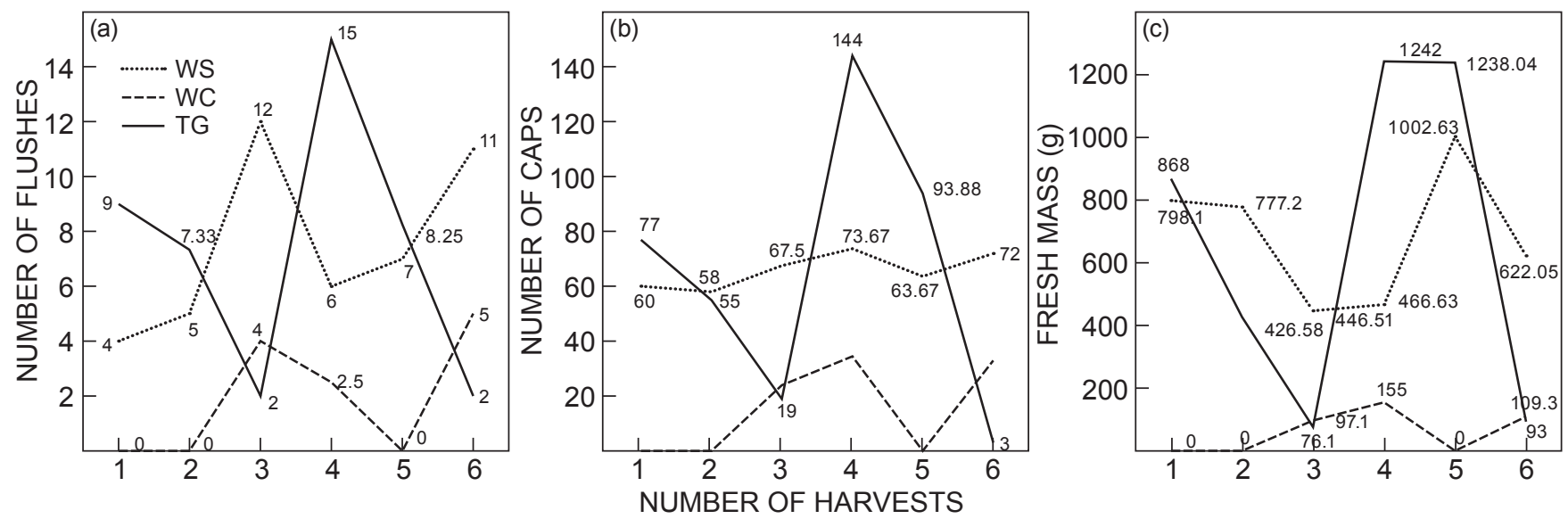

Figure 5: Harvesting times with number of flushes (A), number of caps $(B)$ and fresh mass $(C)$ of oyster mushrooms produced from 15 April to 28 May 2011 

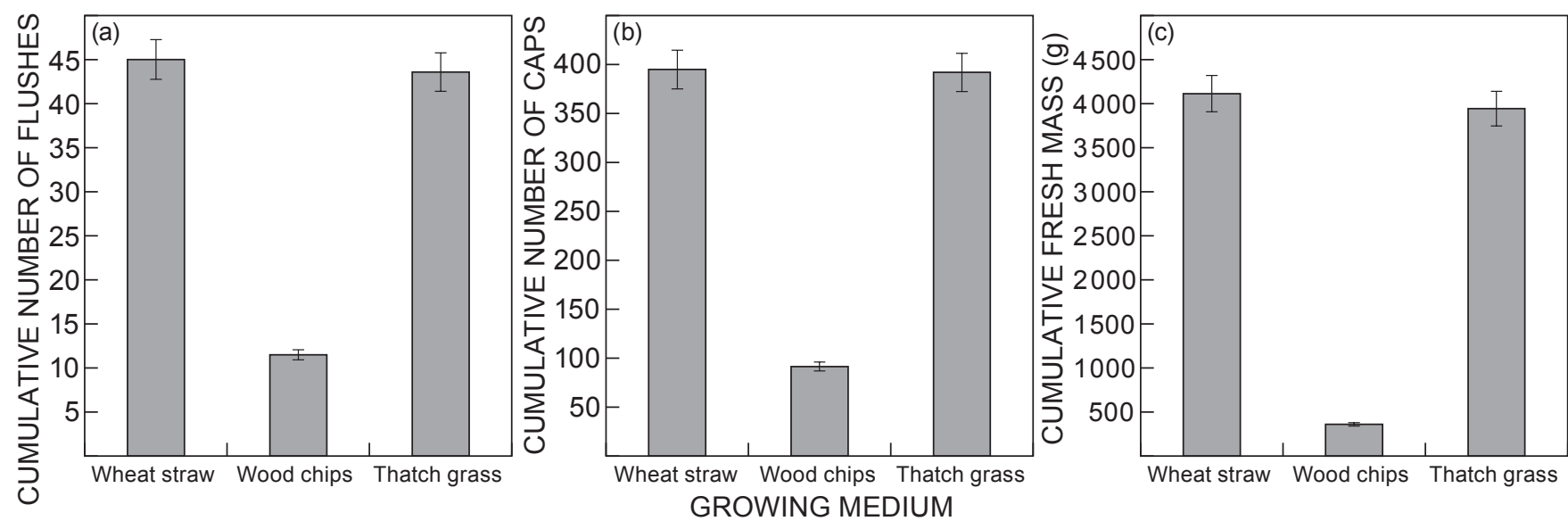

Figure 6: Cumulative number of flushes (a) and caps (b) and fresh mass (c) of oyster mushrooms from different growing media. Error bars represent LSD means $(P<0.05)$

straw, rice straw + wheat straw, rice straw + paper, sugarcane bagasse and sawdust). In general, both thatch grass and wheat straw produced high numbers of flushes and caps and high fresh mass, which increased yield. This finding was not inconsistent with that of Sofi et al. (2014), who reported that wood chips in combination with wheat straw had the highest yield compared with single usage of wheat straw and waste paper substrates.

\section{Yield of oyster mushrooms}

Cumulative number of flushes produced was significantly different $(P<0.05)$ among all treatments (wheat straw, thatch grass and wood chips). Wheat straw (45) had the highest cumulative number of flushes produced followed by thatch grass (44) and wood chips (12) (Figure 6). Kumari and Achal (2008) cultivated Pleurotus ostreatus on different substrates and reported that the highest yield was achieved on wheat straw, followed by the combination of paddy straw and wheat straw. These authors' findings were similar in that the highest yield was on wheat straw, but the other substrates used were different to those of the present study.

Cumulative number of caps produced on both wheat straw and thatch grass differed significantly $(P<0.05)$ compared with wood chips. Both wheat straw (395) and thatch grass (392) had higher cumulative number of caps compared with wood chips (91.50) (Figure 6).

Both wheat straw and thatch grass differed significantly from wood chips in terms of cumulative fresh mass of oyster mushrooms. Wheat straw (4113 g) and thatch grass (3 $944 \mathrm{~g}$ ) produced the highest cumulative fresh mass of oyster mushrooms compared with that of wood chips (361 g) (Figure 6). This indicated that both wheat straw and thatch grass produced greater yields. Thatch grass also showed potential as an alternative to wheat straw when considering the cumulative fresh mass produced.

\section{Conclusions}

Wheat straw accelerated the rate of colonisation, which helped to avoid contamination with parasitic fungi (Trichoderma spp.). However, with thatch grass the rate of colonisation recovered at a later stage after contamination had occurred. This indicated that both wheat straw and thatch grass accelerated the rate of colonisation, although at different stages. Both wheat straw and thatch grass suppressed contamination due to quick coverage of mycelia in the culture bag. Wood chips had a high rate of contamination by parasitic fungi (Trichoderma spp.) due to slow mycelial coverage of the culture bags. Although thatch grass had minimal contamination at an advanced stage of mycelia coverage, it is still advisable to be used as an alternative substrate only if wheat straw is not available. Thatch grass is recommended because it contains three important nutrients $(\mathrm{N}, \mathrm{P}$ and $\mathrm{Mg}$ ) required by oyster mushrooms, whereas wheat straw contains only $\mathrm{N}$ and $\mathrm{Mg}$ in high quantities. Both wheat straw and thatch grass produced high cumulative numbers of flushes and caps and high fresh mass of oyster mushrooms. In general, thatch grass is shown to be useful as an alternative substrate to wheat straw because it produces a higher yield of oyster mushrooms.

Acknowledgements - Thanks to the ARC-ITSC and AgriSETA for providing the funds and the facilities necessary to conduct this study. Thanks also to all my colleagues at ARC-ITSC who participated in this work.

\section{References}

Bandara WMMS, Seneviratne G, Koolasooriya SA. 2006. Interactions among endophytic bacteria and fungi: effects and potentials. Journal of Biosciences 31: 645-650.

Bernardi E, Donini LP, Minotto E. 2007. Cultivation of three Pleurotus (Jacq.: Fr.) P. Kummer species on pasteurized elephant grass (Pennisetum purpureum) substrate. International Journal of Medicinal Mushrooms 9: 373-378.

Bughio I. 2001. Yield performance of oyster mushroom, Pleurotus ostreatus (Jacq. ex. Fr) Kummer on combination of different straws. MSc thesis, Sindh Agriculture University, Tandojam, Pakistan.

Chiu SW, Chan YH, Law SC, Cheung KT, Moore D. 1998. Cadmium and manganese in contrast to calcium reduce yield and nutritional values of the edible mushroom Pleurotus lumonarius. Mycological Research 102: 449-457. 
Cohen R, Persy L, Hadar Y. 2002. Biotechnological applications and potential of wood-degrading mushrooms of the genus Pleurotus. Applied Microbiology and Biotechnology 58: 582-594.

Dunkwal V, Jood S. 2009. Effect of substrates on nutrient composition of oyster mushroom (Pleurotus sajor-caju). Journal of Dairying, Foods and Home Sciences 28: 132-136.

Greenfield H, Southgate DAT. 2003. Food composition data production, management and use (2nd edn). Rome: Food and Agricultural Organization of the United Nations.

Harris LE. 1970. Nutrition research techniques for domestic and wild animals, vol. 1. Logan, UT: Animal Science Department, Utah State University.

Isaac RA, Johnson WC Jr. 1992. Determination of $\mathrm{P}, \mathrm{K}, \mathrm{Ca}, \mathrm{Mg}$, $\mathrm{Mn}, \mathrm{Fe}, \mathrm{Al}, \mathrm{B}, \mathrm{Cu}$ and $\mathrm{Zn}$ in plant tissue by emission spectroscopy. In: Plank CO (ed.), Plant analysis reference procedures for the southern region of the United States. Southern Cooperative Series Bulletin 368. Athens, GA: Georgia Agricultural Experiment Stations, University of Georgia. pp 41-43.

Kang SW. 2004. What is oyster mushroom. In: Mushroom Growers' Handbook 1. Seoul: MushWorld. pp 48-51.

Khan NA. 2009. Studies on cultivation of oyster mushroom on commonly available agricultural wastes in Pleurotus. PhD thesis, University of Agriculture, Faisalabad, Pakistan.

Khan SM, Nawaz A, Ali MA, Ahmad T, Khan NA, Rehman AU. 2012. Response of oyster mushroom on different agricultural wastes of southern Punjab. Pakistan Journal of Agricultural Science 49: 127-130.

Kumari D, Achal V. 2008. Effect of different substrates on the production and non-enzymatic antioxidant activity of Pleurotus ostreatus (oyster mushroom). Life Science Journal 5(3): 73-76.

Kwon H, Kim BS. 2004. Bag cultivation. In: Mushroom Growers' Handbook 1. Seoul: MushWorld. pp 139-152.

Labuschagne PM, Eiker A, Aveling T, de Meillon S, Smith MF. 2000. Influence of wheat cultivars on straw quality and $P$. ostreatus cultivation. Bioresource Technology 71: 71-75.

Mane VJ, Patil SS, Syed AA, Baig MMV. 2007. Bioconversion of low quality lignocellulosic agricultural wastes into edible protein Pleurotus sajor-caju (Fr.). Singer Journal of Zhejiang University Science 8: 745-751.

Mertens DR. 2002. Gravimetric determination of amylase-treated neutral detergent fiber in feeds with refluxing in beakers or crucibles. Journal of AOAC International 85: 1217-1240.

Mondal SR, Rehana MJ, Noman MS, Adhikary SK. 2010. Comparativestudy on growth and yield performance of oyster mushroom (Pleurotus florida) on different substrates. Journal of Bangladesh Agricultural University 8: 213-220.

Pokhrel CP, Yadav RKP, Ohga S. 2009. Effects of physical factors and synthetic media on mycelial growth of Lyophyllum decastes. Journal of Ecobiotechnology 1: 46-50.

Poppe J. 2004. Agricultural wastes as substrates for oyster mushroom. In: Mushroom Growers' Handbook 1. Seoul: MushWorld. pp 75-85.

Prakash P, Samundeeswari R, Vivek C, Chitra Devi A. 2011.
The influence of potassium humate on Pleurotus florida. World Journal of Science and Technology 1: 28-31.

Ragunathan R, Gurusamy R, Palaniswamy M, Swaminathan K. 1996. Cultivation of Pleurotus species on various agro-residues. Food Chemistry 55: 139-144.

Rajapakse JC, Rubasingha P, Dissanayake NN. 2007. The potential of using cost-effective compost mixtures for oyster mushroom (Pleurotus species) cultivation in Sri Lanka. Tropical Agricultural Research and Extension 10: 29-32.

Rajarathnam S, Bano Z, Miles PG. 1988. Pleurotus mushrooms. Part IB. Pathology, in vitro and in vivo growth requirements, and world status. Critical Reviews in Food Science and Nutrition 26: 243-311.

Sanchez C. 2004. Modern aspects of mushroom culture technology. Applied Microbiology and Biotechnology 64: 756-762.

Selvi S, Uma DP, Suja S, Marugan S, Chinnaswamy P. 2007. Comparison of non-enzymic antioxidant status of fresh and dried form of Pleurotus florida and Calocybe indica. Pakistan Journal of Nutrition 6: 468-471.

Shah ZA, Ashraf M, Ishtiag Ch M. 2004. Comparative study on cultivation and yield performance of oyster mushrooms (Pleurotus ostreatus) on different substrates (wheat straw, leaves, sawdust). Pakistan Journal of Nutrition 3: 158-160.

Sharma S, Yadav RKP, Pokhrel CP. 2013. Growth and yield of oyster mushroom (Pleurotus ostreatus) on different substrates. Journal on New Biological Reports 2: 3-8.

Sofi B, Ahmad M, Khan M. 2014. Effect of different grains and alternate substrates on oyster mushroom (Pleurotus ostreatus) production. African Journal of Microbiology Research 8: 1474-1479.

Tan KK. 1981. Cotton waste is a fungus (Pleurotus) good substrate for cultivation of Pleurotus ostreatus the oyster mushroom. Mushroom Science 11: 705-710.

Tesio L. 2003. Measuring behaviours and perceptions: Rasch analysis as a tool for rehabilitation research. Journal of Rehabilitation and Medicine 35: 105-115.

Upadhay RC, Verma RN, Singh SK, Yadav MC. 2002. Effect of nitrogen supplementation in Pleurotus species. In: Sanchez JE, Huerta G, Montiel E (eds), Mushroom biology and mushroom products. Morelos: Universidad Autonoma del Estado de Morelos. pp 225-235.

van Niewenhuijzen B. 2007. Small-scale mushroom cultivation - 2. Agaricus and Volvariella. Agrodok 41. Wageningen: Agromisa Foundation and CTA.

Wang D, Sakoda A, Suzuki M. 2001. Biological efficiency and nutritional value of $P$. ostreatus cultivated on spent beet grain. Bioresource Technology 78: 293-300.

Wood DA, Hartley RD. 1988. Conclusions and recommendations. In: Zadrazil F, Reiniger P (eds), Treatment of lignocellulosics with white rot fungi. London: Elsevier Applied Science. pp 115-117.

Yildiz S, Yildiz UC, Gezer ED, Temiz A. 2002. Some lignocellulosic wastes used as raw material in cultivation of the Pleurotus ostreatus culture mushroom. Process Biochemistry 38: 301-306. 